\title{
Leisure Satisfaction of Sports Science Students
}

\author{
Özden Tepeköylü Öztürk ${ }^{1}$ \\ ${ }^{1}$ Faculty of Sport Sciences, Pamukkale University, Denizli, Turkey \\ Correspondence: Özden Tepeköylü Öztürk, Faculty of Sport Sciences, Campus of Kınıklı, Pamukkale University, \\ 20020, Denizli, Turkey.
}

Received: November 19, 2018

Accepted: December 27, 2018

Online Published: March 10, 2019

doi:10.5539/ies.v12n4p42

URL: https://doi.org/10.5539/ies.v12n4p42

\begin{abstract}
The aim of this study is to determine the leisure satisfaction levels of students who study sports sciences. In addition, in the study, the satisfaction levels of the students were compared according to their gender, departments and the most preferred activity type in leisure. The research was in quantitative descriptive design and consisted of a total of 379 sports sciences students, including 144 female and 235 men. The "Leisure Satisfaction Scale" developed by Beard and Raghep (1992) which is adapted to Turkish by Gökçe and Orhan (2011) and the "Personal Information Form" developed by the researcher were used as data collection tools. T-test, ANOVA and one-way MANOVA test techniques were used in the analysis of the data. According to the research findings, the leisure satisfaction of the students of Sports Sciences has been observed to be high level. In general, it was found that leisure satisfaction of those who do most physical activity is higher than those who did social, intellectual and artistic etc. activity. According to the gender factor, leisure satisfaction total score did not make a difference, but it was seen that female had higher scores than psychological and relaxation dimensions. In the comparisons between the departments, it was determined that the recreation department had more leisure satisfaction than the coaching and physical education teaching department students. It has been observed that the highest score section is recreation and the lowest score section is coaching. Finally, the research findings were discussed.
\end{abstract}

Keywords: leisure satisfaction, university students, leisure

\section{Introduction}

Science and technological developments that facilitate human life have created changes in the time periods allocated for compulsory and non-compulsory activities during the day. Although the intensity of compulsory vital activities has increased as a quality, the time interval has decreased, but the time interval allocated for non-compulsory activities has started to increase. This situation has caused the leisure and activities to be reminded more quantitatively and qualitatively. Leisure refers to the leisure zone that remains after the basic requirements in life are imposed by restrictions, obligations and certain social responsibilities (Torkildsen, 1992; Hemingway, 1996; Mull et al., 1997). Activities in leisure provide physical, emotional and social gains (Mahoney \& Stattin, 2000; McLean \& Hurd, 2015, p. 2). For this reason, the concept of leisure, the nature of leisure activities and the psychological, mental and physical benefits of these activities have become increasingly important (Gökçe \& Orhan, 2011).

Leisure satisfaction refers to the positive feelings that individuals get from their leisure experiences and the degree of satisfaction they get from these experiences (Beard \& Ragheb, 1980). Since leisure participants participate in their activities with various goals and expectations, it is a factor that cannot be ignored in understanding leisure behavior (Lee, Shapper, \& Kang, 2005). There are six sizes (psychological, educational, social, relaxation, physiological, aesthetical). One of these psychological dimensions is related to the psychological elements of leisure satisfaction. Individuals can attain psychological satisfaction when they meet their needs for self-realization leisure, when they have a sense of success and when they can express themselves. The search for intellectual stimuli about themselves and their environment at the leisure of people is about the educational dimension. It reflects how much information is perceived from leisure experiences. On the social level, participation in voluntary groups or communities is the focus of establishing freely chosen new relationships. The relaxation dimension is related to the elimination of tension and stress related to work and life. Physiological dimension, renewed physically, indicates improved health and satisfaction with the strengthening of the heart, circulation and muscle system. Finally, in the Aesthetical dimension, it is important that the visual 
design and health of recreation areas are appropriate for leisure experiences to be interesting and to make them happy (Beard \& Ragheb, 1980). The leisure satisfaction studied in six dimensions is related to or interacted with a variety of factors that increase or decrease the quality of life. For example, it affects the general life satisfaction perceptions of individuals (Huang \& Carleton, 2003; Wang, Chen, Lin, \& Wang, 2008; Yerlisu-Lapa, 2013; Akgül, Ayyıldız, \& Karaman, 2014; Kim, Schilling, Kim, \& Han, 2016; Choi \& Yoo, 2017). It has recently been observed that there is a relationship between happiness, which is a very researched concept in literature (Spiers \& Walker, 2009; Kaya, 2016). It is also thought to be a factor that contributes to the avoidance of stress and routines related to life (Parham, 1996, quoted by Gökçe \& Orhan, 2011). Therefore, it can be considered as an important variable not only in leisure but also in general life.

It is of course important for each age group to participate in free-time structured activities, to obtain personal benefits from these activities and to maintain a complete satisfaction. However, it is even more important for young people with high energy to participate in such activities in a productive period and to be able to direct their energies towards the right direction. Considering that there is a positive relationship between participation in leisure and satisfaction (Huang \& Carleton, 2003; Sivan, Fung, Fung \& Ruskin, 2013), it can be said that participation will be low or not in an environment where there is no satisfaction. For this reason, it is an issue to be investigated how much satisfaction young groups receive from their leisure. In addition, studies on university students from the youth age have shown that satisfaction facilitates coping with academic stress (Misra \& McKean, 2000) and stressful situations (Chun, Lee, Kim, \& Hio, 2012), related to subjective well-being (Walker \& Ito, 2016) and extraversion, and helps to maintain emotional balance ( $\mathrm{Lu} \& \mathrm{Hu}, 2005$ ). In this regard, leisure satisfaction is a parameter that should be examined on young people. Therefore, in the study, it was tried to determine the leisure satisfaction levels of the students studying in sports sciences. In addition, satisfaction levels of the students were compared according to their gender, departments and the most preferred activity type in leisure.

\section{Method}

\subsection{Research Design and Participants}

The study was a quantitative study and a descriptive evaluation was carried out. The sample consisted of 144 female $\left(x_{\text {age } \text { female }}=21.29 \pm 1.62\right)$ and 235 male $\left(x_{\text {age_male }}=22.28 \pm 2.65\right)$ for a total of 379 students $(x$ age $=21.87 \pm 2.269$ ) who were educated in the faculties of Sports Sciences in Turkey. The appropriate sampling technique was used to determine the sample. Students are included in the study based on volunteerism.

\subsection{Data Collection Tools}

In this study, "Leisure Satisfaction Scale" (LSS) developed by Beard and Raghep (1992) and adapted to Turkish by Gökçe and Orhan (2011) and "Personal Information Form" developed by the researcher (PIF) was used as data collection tools.

\subsubsection{Leisure Satisfaction Scale (LSS)}

In this study, LSS used to determine the leisure satisfaction of sports science students consisted of 24 questions, (1) almost not correct, (2) rarely correct, (3) sometimes correct, (4) often correct, (5) is almost always correct in the 5-dimensional scale. There are six sub-dimensions (psychological, education, social, relaxation, physical and Aesthetical) on the scale without reverse materials. The high score obtained from the scale shows that leisure satisfaction is also high (Gökçe \& Orhan, 2011).

Six factor structures were verified in the analysis of the Turkish validity of the scale. Significant correlations were found in all sub-scales according to Pearson product moments coefficient, which is used to test the validity of the scope. In the reliability analysis conducted by Beard and Ragheb in 1980 for the long form of the scale, it was observed that the Cronbach alpha coefficient for each dimension varied between .85 and .96. In the short form, this coefficient average is .93 (Gökçe \& Orhan, 2011). In the scope of this study, the Cronbach alpha value as the internal consistency coefficient was found to be .91 for the scale.

\subsubsection{Personal Information Form (PIF)}

This is a questionnaire formed by the researchers to collect information about the independent variables of the research. There are questions about the participants' gender, ages, the most preferred leisure activities, the departments and the classes.

\subsection{Data Analysis}

The data were evaluated using the frequency, arithmetic mean, standard deviation, t-test, ANOVA and one-way MANOVA test techniques. The differences in the lower dimensions of LSS were examined with a one-way 
MANOVA according to the most preferred leisure activity type and the learning section factor. The differences in gender factor were determined by using $t$ test because the data did not meet the MANOVA test preconditions (the assumption that covariance matrices were not equal). According to the most preferred leisure activity type and learning department factor, LSS total scores were evaluated using $t$ test and ANOVA. Whether the data meet the prerequisites of parametric tests, it was decided by examining the skewness and kurtosis (normal distribution status) values of each sub-dimension and Levene (equality of variance) test results. The values of the basefulness and skewness range from -.683 to 605. In the MANOVA analysis, the Box's test was used to test the assumption that the covariance matts of dependent variables were equal throughout the groups. In the same analysis, Wilk's Lambda test was used to test the differences in mean of dependent variables according to groups of independent variables. Cronbach Alpha internal consistency coefficients were calculated to determine the reliability of the scales used in the study. Type 1 error is accepted as $5 \%$.

\section{Results}

Table 1. The result of the descriptive statistics on the leisure satisfaction of the students of sports sciences

\begin{tabular}{lccccc}
\hline & $\mathrm{N}$ & Min. & Max. & $\mathrm{X}$ & Standard error \\
\hline Psychological & 379 & 1.75 & 5.00 & 3.96 & .67 \\
Educational & 379 & 2.00 & 5.00 & 4.04 & .69 \\
Social & 379 & 1.50 & 5.00 & 4.00 & .69 \\
Relaxation & 379 & 2.00 & 5.00 & 4.11 & .66 \\
Physiological & 379 & 1.75 & 5.00 & 3.85 & .69 \\
Aesthetical & 379 & 1.75 & 5.00 & 3.90 & .76 \\
*LS Total & 379 & 2.17 & 5.00 & 3.98 & .54 \\
\hline
\end{tabular}

* Leisure satisfaction

When Table 1 is examined, it is observed that the leisure satisfaction scores of the sports science students are slightly above the average. When the scores related to the sub-dimensions were examined, it was determined that the highest score was related to the relaxation sub-dimension and the lowest score to the physiological sub-dimension. When evaluated in general terms, it can be said that students are satisfied with their leisure.

Table 2. One-way MANOVA results for leisure satisfaction sub-dimensions according to the most preferred leisure activity of sports science students

\begin{tabular}{|c|c|c|c|c|c|c|c|}
\hline Source Of Variance & Dependent Variable & SS & $\mathrm{df}$ & MS & $\mathrm{F}$ & $\mathrm{p}$ & $\eta_{\mathrm{p} 2}$ \\
\hline \multirow{6}{*}{$*$ LAT } & Psychological & .293 & 1 & .293 & .645 & .423 & .002 \\
\hline & Educational & 1.267 & 1 & 1.267 & 2.609 & .107 & .007 \\
\hline & Social & 1.836 & 1 & 1.836 & 3.778 & .053 & .010 \\
\hline & Relaxation & 1.357 & 1 & 1.357 & 3.039 & .082 & .008 \\
\hline & Physiological & 11.845 & 1 & 11.845 & 26.228 & .000 & .065 \\
\hline & Aesthetical & .561 & 1 & .561 & .966 & .326 & .003 \\
\hline \multirow{6}{*}{ Error } & Psychological & 171.465 & 377 & .455 & & & \\
\hline & Educational & 183.042 & 377 & .486 & & & \\
\hline & Social & 183.154 & 377 & .486 & & & \\
\hline & Relaxation & 168.297 & 377 & .446 & & & \\
\hline & Physiological & 170.256 & 377 & .452 & & & \\
\hline & Aesthetical & 219.019 & 377 & .581 & & & \\
\hline \multirow{6}{*}{ Total } & Psychological & 6134.188 & 379 & & & & \\
\hline & Educational & 6395.188 & 379 & & & & \\
\hline & Social & 6265.000 & 379 & & & & \\
\hline & Relaxation & 6596.938 & 379 & & & & \\
\hline & Physiological & 5806.375 & 379 & & & & \\
\hline & Aesthetical & 5999.000 & 379 & & & & \\
\hline
\end{tabular}

The results of one-way MANOVA analysis showed that there were significant differences in LS sub-dimensions compared to the most preferred leisure activity type when multiple comparison tables were examined. (Wilks' 
Lambda $=.925 ; \mathrm{F}=5.036 ; \mathrm{p}=.000$ ). In this study, it was observed that there was a significant difference in the physiological sub-dimension of LS and that there was a tendency towards meaningful sub-dimension of social sub-dimension. Accordingly, those who prefer to do the most physical activity (PA) in leisure can be said to provide more physiologically and socially more satisfaction than those who prefer other activities (OA-social, intellectual, artistic, etc.) ( $\left.x_{\text {physiological }} \mathrm{PA}=3.96, x_{\text {physiological }} \mathrm{OA}=3.56 ; x_{\text {Social PA }}=4.04, x_{\text {Social OA }}=3.89\right)$.

T-test was used to compare leisure satisfaction with the total score according to the most preferred leisure activity. According to the analysis results, the total satisfaction of those who prefer the most physical activity in their leisure was found to be higher than those who prefer the other activities $\left(\mathrm{t}(377)=2.585, \mathrm{p}=.010, x_{\mathrm{PA}}=4.02\right.$, $x_{\mathrm{OA}}=3.86$ ).

Table 3. One-way MANOVA results for leisure satisfaction sub-dimensions according to the department of sports science students' education

\begin{tabular}{lccccccc}
\hline Source Of Variance & Dependent Variable & SS & df & MS & F & p & Пp2 \\
\hline & Psychological & 4.428 & 3 & 1.476 & 3.308 & .020 & .026 \\
& Educational & 7.098 & 3 & 2.366 & 5.007 & .002 & .039 \\
& Social & 6.541 & 3 & 2.180 & 4.582 & .004 & .035 \\
Department & Relaxation & 2.162 & 3 & .721 & 1.613 & .186 & .013 \\
& Physiological & 3.477 & 3 & 1.159 & 2.433 & .065 & .019 \\
& Aesthetical & 2.888 & 3 & .963 & 1.666 & .174 & .013 \\
\hline \multirow{5}{*}{ Error } & Psychological & 167.330 & 375 & .446 & & & \\
& Educational & 177.211 & 375 & .473 & & & \\
& Social & 178.448 & 375 & .476 & & & \\
& Relaxation & 167.492 & 375 & .447 & & & \\
& Physiological & 178.624 & 375 & .476 & & & \\
& Aesthetical & 216.693 & 375 & .578 & & & \\
\hline \multirow{5}{*}{ Total } & Psychological & 6134.188 & 379 & & & & \\
& Educational & 6395.188 & 379 & & & & \\
& Social & 6265.000 & 379 & & & & \\
& Relaxation & 6596.938 & 379 & & & & \\
& Physiological & 5806.375 & 379 & & & & \\
& Aesthetical & 5999.000 & 379 & & & & \\
\hline
\end{tabular}

When multiple comparison tables were examined as a result of one-way MANOVA analysis, it was observed that there were significant differences in LS sub-dimensions according to the section factor. (Wilks' Lambda=.924; $\mathrm{F}=1.648 ; \mathrm{p}=.043$ ). When the ANOVA multiple comparison tables were used to determine which sub-dimensions and sub-sections were caused by this difference, it can be said that the students in the recreation department received more leisure satisfaction than the coaching and physical education students about the psychological, educational, social and physiological sub-dimensions.

The comparison of leisure satisfaction total score according to the students' education was done with ANOVA. The results of the analysis showed that the students of the recreation department had significantly higher satisfaction scores than the students of the coaching and physical education teachers; there is no significant difference with the sport management department. The section with the highest score is the recreation and the section with lowest point is the coaching department. $\left(\mathrm{F}_{(375,3)}=4.429, \mathrm{p}=.004, x_{\text {coaching }}=3.91, x_{\text {Physical education }}\right.$ teacher $=3.93, x_{\text {recreation }}=4.22, x_{\text {sports management }}=4.00$ ).

Table 4. T-test result of leisure satisfaction according to gender of sports science students

\begin{tabular}{lccccccc}
\hline Leisure satisfaction & Gender & $\mathrm{N}$ & $\mathrm{X}$ & $\mathrm{sd}$ & $\mathrm{df}$ & $\mathrm{t}$ & $\mathrm{p}$ \\
\hline \multirow{2}{*}{ Psychological } & Female & 144 & 4.07 & .63 & 377 & 2.384 & .018 \\
& Male & 235 & 3.90 & .69 & & & \\
\multirow{2}{*}{ Educational } & Female & 144 & 4.11 & .67 & 377 & 1.414 & .158 \\
& Male & 235 & 4.00 & .70 & & & \\
Social & Female & 144 & 4.06 & .65 & 377 & 1.247 & .213 \\
& Male & 235 & 3.97 & .72 & & & \\
\hline
\end{tabular}




\begin{tabular}{|c|c|c|c|c|c|c|c|}
\hline \multirow{2}{*}{ Relaxation } & Female & 144 & 4.20 & .68 & 377 & 2.062 & .040 \\
\hline & Male & 235 & 4.06 & .65 & & & \\
\hline \multirow{2}{*}{ Physiological } & Female & 144 & 3.88 & .71 & 377 & .690 & .491 \\
\hline & Male & 235 & 3.83 & .68 & & & \\
\hline \multirow{2}{*}{ Aesthetical } & Female & 144 & 3.95 & .75 & 377 & .962 & .337 \\
\hline & Male & 235 & 3.87 & .76 & & & \\
\hline \multirow{2}{*}{ Leisure Satisfaction Total } & Female & 144 & 4.04 & .53 & 377 & 1.857 & .064 \\
\hline & Male & 235 & 3.94 & .54 & & & \\
\hline
\end{tabular}

When Table 4 is examined, it is seen that there is a statistically significant difference of leisure satisfaction in psychological and relaxation sub-dimensions. Accordingly, it can be said that female students have higher leisure satisfaction in both sub-dimensions. No significant difference was found between the genders for other subscales and LS total score.

\section{Discussion}

According to the findings of the research, it is seen that the leisure satisfaction scores of the sports science students are slightly above the average score and thus they are satisfied with their leisure. When assessed on the basis of sub-dimensions, they stated that they provide the most satisfaction with relaxation and socialization and least with physical. When literature is examined, it is seen that leisure satisfaction is similar in middle level in studies conducted on university students and young individuals, and in terms of satisfaction at most in relaxation, at least in physiological is obtained from the leisure activities (Spiers \& Walker, 2009; Kaya, 2014; Sönmezoğlu et al., 2014). In the study of Muzindutsi and Masango (2015), parallel findings were obtained, and the leisure satisfaction of university students was found to be moderate and the highest scores were in Relaxation size. In other studies conducted on similar groups, leisure satisfaction scores are shown to be moderate with minor differences (Ardahan \& Yerlisu-Lapa, 2010; Ito et al., 2017). There are many factors affecting the level of leisure satisfaction of individuals. Which leisure activity is performed (Munchua et al., 2003; Derman et al., 2016), whether the leisure activity is active or passive (Ardahan \& Yerlisu-Lapa, 2010), leisure participation (Sivan, Fung, Fung, \& Ruskin, 2013 ) etc. In this study, only the type of activity was questioned and the scores of those who preferred the most physical activity were high $(x=4.02, \pm .54)$. Those who prefer other activities have lowered their overall group average. However, studies on the same group with the above-mentioned variables will be more descriptive of the reasons.

The students of the recreation department had similar satisfaction with the sports management department and more satisfaction with coaching and physical education department compared to their leisure. When evaluated on the basis of sub-dimensions, it was determined that the difference is in psychological, educational, social and physiological dimensions. It was determined that the highest score belongs to the recreation department and the lowest score belongs to the physical education teacher. The high score of the recreation department is especially welcome in the educational dimension. Because the students of the Department of recreation take courses on various organizations, management, career, planning, recreation education, activities and practice related to recreation and leisure during the education process. This may have created the perception and awareness of leisure planning, effective evaluation, and freedom of choice. Thus, the physical, emotional and social gains from leisure may be higher, so they may increase their leisure satisfaction.

When the results of the study were evaluated according to gender factors, there was no difference between gender and general satisfaction scores, whereas psychological and relaxation dimensions of female students provided more satisfaction than males. When the literature is examined, there are different findings about gender differences. In some studies, it is seen that there is no significant difference between leisure satisfaction of men and women (Siegenthaler \& O'Dell, 2000; Yerlisu-Lapa, 2013; Derman et al., 2016), while some studies show significant differences (Vong, 2005). Vong (2005) says that men are more satisfied than women in their youth and in most of their lives; Gökçe (2008) stated that women in terms of relaxation provide more satisfaction in men in physiological sense. However, in contrast to this study, it is observed that the leisure satisfaction of males is generally higher in the literature than in female satisfaction levels (Misra \& McKean, 2000; Kabanoff, 1982). Korkut (1997) stated that in the process of growth, women and men are supported and accepted by different behaviors while socializing in society. This situation may affect the behaviors of the individual in shaping and their expectations from life and life events. Therefore, students of different sexes who participate in similar leisure activities with similar opportunities may have different satisfaction. Muzindustsi and Masango (2015) attributed this to gender equality and explained that the different results of the study were not reach equal leisure resources 
for individuals in different societies.

\section{Conclusion and Recommendations}

When this study is evaluated together with other studies, university students provide moderate satisfaction from leisure activities. Considering the different parameters that will increase the quality of human life, which is effective in the free use of time, physical, psychological, social and cognitive benefits and leisure satisfaction, this level may not be enough. However, there must be some explanatory studies that will determine why moderate time satisfaction is at these levels. It is suggested that questions should be added to the studies to determine the level of leisure satisfaction, to add questions about participation, to the way of participation, to the participation area, with whom and to the relational findings. $\mathrm{n}$ practical terms, it is thought that more structuring needs to be done in universities about campus recreation. On-campus structured activities can be put into practice, several courses can be added to curriculums in different departments for effective evaluation of leisure, or information seminars can be organized for students.

\section{References}

Akgül, B. M., Ayyıldız, T., \& Karaman, M. (2014). Examination of leisure satisfaction levels of individuals participating in recreative activities through sports centers with regard to some variables. Niğde University Journal of Physical Education and Sport Science, 8(3), 278-287.

Ardahan, F., \& Yerlisu-Lapa, T. (2010). An examination of leisure satisfaction level of university students with regard to gender and income. Hacettepe Journal of Sport Sciences, 21(4), 129-136.

Beard, J. G., \& Ragheb., M. G. (1980). Measuring leisure satisfaction. Journal of Leisure Research, 12, 20-33. https://doi.org/10.1080/00222216.1980.11969416

Choi, S., \& Yoo, Y. (2017). Leisure attitude and satisfaction with leisure and life: proposing leisure prioritization and justification. World Leisure Journal, 59(2), 140-155. https://doi.org/10.1080/16078055.2016.1216886

Chun, S., Lee, Y., Kim, B., \& Heo, J. (2012). The contribution of leisure participation and leisure satisfaction to stress-related growth. Leisure Sciences, 34, 436-449. https://doi.org/10.1080/01490400.2012.714704

Derman, E., Yerlisu-Lapa, T., \& Certel, Z. (2016). A comparison of leisure satisfaction levels of university students according to gender and different activities. International Sports Sciences Tourism and Recreation Student Congress, 27-29 May, Gaziantep, Turkey (Abstract Book, p. 108).

Gökçe, H. (2008) Examining of the leisure satisfaction with the relation between life satisfaction and socio demographic variables (M. Sc. Thesis in Psycho - Social Fields in Sports, Pamukkale University, Institute of Health Sciences, Denizli, Turkey). Retrieved from https://tez.yok.gov.tr/UlusalTezMerkezi/tezSorguSonucYeni.jsp

Gökçe, H., \& Orhan, K. (2011). Validity and reliability study of the leisure satisfaction scale (LSS) into Turkish. Hacettepe. Journal of Sport Sciences, 22(4), 139-145.

Hemingway, J. L. (1996). Emancipating leisure: The recovery of freedom in leisure. Journal of Leisure Research, 28(1), 27-43. https://doi.org/10.1080/00222216.1996.11949759

Huang, C. Y. \& Carleton, B. (2003). The Relationship among Leisure Participation, Leisure Satisfaction, and Life Satisfaction of College Students in Taiwan. Journal of Exercise Scienece \& Fitness, 1(2), 129-132.

Ito, E., Walker, G. J., Liu, H., \& Mitas, O. (2017) A cross-cultural/ national study of canadian, chinese, and japanese university students' leisure satisfaction and subjective well-being. Leisure Sciences, 39(2), 186-204. https://doi.org/10.1080/01490400.2016.1165637

Kabanoff, B. (1982). Occupational and sex differences in leisure needs and leisure satisfaction. Journal of Occupational Behaviour, 3, 233-245. https://doi.org/10.1002/job.4030030304

Kaya, S. (2016). The relationship between leisure satisfaction and happiness among college students. Universal Journal of Educational Research, 4(3), 622-631. https://doi.org/10.13189/ujer.2016.040322

Kim, J., Schilling, M. L., Kim, M., \& Han, A. (2016). Contribution of leisure satisfaction, acceptance disability, and social relationship to life satisfaction among Korean individuals with intellectual disability. Journal of Mental Health Research in Intellectual Disabilities, 9(3), 157-170. https://doi.org/10.1080/19315864.2016.1182237

Korkut, F. (1997). Üniversite öğrencilerinin iletişim becerilerinin değerlendirilmesi. IV. Uluslararası Eğitim Bilimleri Kongresi Bildirileri. Anadolu Üniversitesi, Eskişehir, Türkiye. (Congress Book, pp. 208-2018) 
Lee, B. K., Shafer, C. S., \& Kang, I. (2005). Examining relationships among perceptions of self, episode-specific evaluations, and overall satisfaction with a leisure activity. Leisure Sciences, 27(2), 93-109. https://doi.org/10.1080/01490400590912006

Lu, L., \& Hu, C. H. (2005). Personality, leisure experiences and happiness. Journal of Happiness Studies, 6, 325-342. https://doi.org/10.1007/s10902-005-8628-3

Mahoney, J. L., \& Stattin, H. (2000). Leisure activities and adolescent antisocial behavior: The role of structure and social context. Journal of Adolescence, 23, 113-127. https://doi.org/10.1006/jado.2000.0302

McLean, D. D., \& Hurd, A. R. (2015). Kraus' recreation and leisure in modern society (10th ed.). USA, Jones \& Barlet Learning, LI.C., An Ascend Learning Company.

Misra, R., \& McKean, M. (2000). College students' academic stress and ts relation to their anxiety, time management, and leisure satisfaction. American Journal of Health Studies, 16(1), 41-51.

Mull, R. F., Bayless, K. G, Ross, C. M., \& Jamieson, L. M., (1997). Recreational sport management (3rd ed.). USA, Human Kinetics.

Munchua, M. M., Lesage, D. M., Reddon, J. R., \& Bandham, T. D. (2003). Motivation, satisfaction, and perceived freedom: a tri-dimensional model of leisure among young offender. Journal of Offender Rehabilitation, 38(1), 53-64. https://doi.org/10.1300/J076v38n01_05

Muzindutsi, P. F., \& Masango, Z. (2015). Determinants of leisure satisfaction among undergraduate students at a South African University. International Journal of Business and Management Studies, 7(2), 1-15.

Siegenthaler, K. L., \& O'dell, I. (2000). Leisure attitude, leisure satisfaction, and perceived freedom in leisure with family dyads. Leisure Sciences, 22, 281-296. https://doi.org/10.1080/01490409950202302

Sivan, A., Fung, A., Fung, L., \& Ruskin, H. (2013). Determinants of participation disposition in leisure among Hong Kong school students. Society and Leisure, 25(1), 155-170. https://doi.org/10.1080/07053436.2002.10707582

Sönmezoğlu, U., Polat, E., \& Aycan, A. (2014). Youth center members and according to some variables levels of leisure satisfaction. International Journal of Science Culture and Sport, Special Issue (1), 219-229. https://doi.org/10.14486/IJSCS91

Spiers, A., \& Walker, G. J. (2009). The effects of ethnicity and leisure satisfaction on happiness, peacefulness, and quality of life. Leisure Sciences, 31, 84-99. https://doi.org/10.1080/01490400802558277

Torkildsen, G. (1992). Leisure recreation management (3rd ed.). London, E \& FN Spon, An Impirint of Chapman \& Hall.

Vong, T. N. (2005). Leisure satisfaction and quality of life in Macao, China. Leisure Studies, 24(2), 195-207. https://doi.org/10.1080/02614360412331313502

Walker, G. J., \& Ito, E. (2016). Mainland Chinese Canadian 1mmigrants' leisure satisfaction and subjective well-being: Results of a two-year longitudinal study. Leisure Sciences, 39(2), 174-185. https://doi.org/10.1080/01490400.2016.1156040

Wang, E. S. T., Chen, L. S. L., Lin, J. Y. C., \& Wang, M. C. H. (2008). The relationship between leisure satisfaction and life satisfaction of adolescents concerning online games. Adolescence, 43(169), 177-184.

Yerlisu-Lapa, T. (2013). Life satisfaction, leisure satisfaction and perceived freedom of park recreation participants. Social and Behavioral Sciences, 93, 1985-1993.

\section{Copyrights}

Copyright for this article is retained by the author(s), with first publication rights granted to the journal.

This is an open-access article distributed under the terms and conditions of the Creative Commons Attribution license (http://creativecommons.org/licenses/by/4.0/). 